\section{New record of the earthworm Drawida papillifer papilliferStephenson from West Bengal, India}

\author{
A. Chowdhury ${ }^{1}$, A.K. Hazra ${ }^{2}$ \& A.P. Nandi ${ }^{3}$ \\ ${ }^{1}$ Present Address: Birati High School (H.S.), P.O. Birati, Kolkata, \\ West Bengal 700051, India \\ 'Zoological Survey of India, 'M' Block, New Alipore, Kolkata, West \\ Bengal 700053, India \\ ${ }^{3}$ Department of Zoology, University of Burdwan, Rajbati, Burdwan, \\ West Bengal 713104, India \\ Email: ${ }^{1}$ amitshampa84@ rediffmail.com
}

Perrier (1872) was first to report of an earthworm species Perichaeta houlleti from West Bengal. Thereafter Beddard (1883, 1900, 1901, 1902), Michaelsen (1907, 1910), Stephenson $(1916,1917,1920,1923)$ had contributed to the taxonomic studies of earthworm from West Bengal. Later a considerable work has been done by Gates' (1937, 1938 a, b, 1951, 1958), Halder \& Julka (1967), Julka (1975), Soota \& Halder (1977, 1981), Halder (1998), Chowdhury \& Hazra (2008, in press), Chowdhury et al. (2008, in press). So far, 64 species of earthworm under 26 genera were reported from West Bengal. During the studies on earthworm, the present species was collected from north 24 parganas District (23015'2"$\left.22^{\circ} 11^{\prime} 66^{\prime} \mathrm{N} \& 8^{\circ} 05^{\prime}-88^{\circ} 20^{\prime} \mathrm{E}\right)$ of West Bengal. The species Drawida papillifer papillifer hitherto not recorded from West Bengal. Details of the species discussed herewith.

\section{Diagnostic characters:}

External: Length $70-125 \mathrm{~mm}$; diameter $3-5 \mathrm{~mm}$. Segments 120-170. Clitellum red, ix-xiv. Colour bluish or purplish. Setae lumbricine. Setae, $a a<b c, d d=$ or $>1 / 2 c$. Male pores very small, superficial without protrusible porophores, paired, in $\mathrm{x}$, at or just lateral to $b$ or nearer to middle of $b c$, each in a whitened semicircular area with base at 10/11. Spermathecal pores paired in $7 / 8$, very small, at or slightly median to $c$. Genital markings small, circular to shortly elliptical and transverse translucent area, in vii-viii and $x$-xi near spermathecal and

Date of publication (online): 26 February 2010

Date of publication (print): 26 February 2010

ISSN $0974-7907$ (online) | 0974-7893 (print)

Editor: M. Gobi

\section{Manuscript details:}

Ms \# 02139

Received 09 February 2009

Final received 05 December 2009

Finally accepted 04 February 2010

Citation: Chowdhury, A., A.K. Hazra \& A.P. Nandi (2010). New record of the earthworm Drawida papillifer papillifer Stephenson from West Bengal, India Journal of Threatened Taxa 2(2): 716-717.

Copyright: () A. Chowdhury, A.K. Hazra \& A.P. Nandi 2010. Creative Commons Attribution 3.0 Unported License. JoTT allows unrestricted use of this article in any medium for non-profit purposes, reproduction and distribution by providing adequate credit to the authors and the source of publication.

Acknowledgements: Authors are indebted to Dr. J. M. Julka, Emeritus scientist, Zoological Survey of India, Solan for confirming the earthworm species. Authors are grateful to the Director, Zoological Survey of India for providing laboratory facilities

OPEN ACGESS | FREE DOWNLOAD
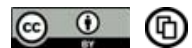

male pores, occasionally in other positions on vii-xii. Female pores paired at or just behind 11/12. Nephropores at or near $d$, somewhat more dorsal in viii (Image 1 \& Fig. 1).

Internal: Septa all present from $4 / 5,5 /$ 6-9/10 muscular. Gizzards 2-4, in xiii-xx. Intestinal origin in xxiii. Intestinal caeca and supra-intestinal glands absent. Holonephridia in iii and posterior segments. Nephridia of $\mathrm{x}$, present in adults. Sperm ducts short, $5-10 \mathrm{~mm}$ long. Capsular prostates paired, in $\mathrm{x}$. Prostates 2-3 mm long. Spermathecal diverticula saccular, with a short stalk, 2-3 $\mathrm{mm}$ long in vii. Genital marking glands small, spheroidal to ellipsoidal, beneath longitudinal musculature.

Earlier Records: Gates (1972) recorded this species from Meghalaya.

Remarks: In India, so far, this species was known to occur only in Meghalaya. Therefore, this study indicates the species Drawida papillifer papillifer recorded for the first time from West Bengal. Its' present record from West Bengal of great significance as its range is now extended to Gangetic plain. No appreciable variation observed in this studied species from the earlier observations of Gates (1972). In this survey, this species were recorded near muddy canal with high amount of decomposed and semi decomposed organic matter in an orchard. Sub soil temperature 25.5 to $29.5^{\circ} \mathrm{C}$, sub soil relative humidity 74 to $93.5 \%$, soil organic carbon 1.08 to $1.92 \%$ and soil pH 6.4 to 6.75 were recorded in this site during this study period.

\section{References}

Beddard, F.E. (1883). Note on some earthworms from India. Annals and Magazine of Natural History (Series 5) 12: 213-224.

Beddard, F.E. (1900). On a new species of earthworm from India belonging to the genus Amyntas. Proceedings of the Zoological Society of London 1900: 998-1002.

Beddard, F.E. (1901). Contribution to the knowledge of the structure and systematic arrangement of earthworms. Proceedings of the Zoological Society of London 1901: 187-206.

Beddard, F.E. (1902). On two new earthworms of the family Megascolecidae. Annals and Magazine of Natural History (Series 7) 9: 456-463.

Chowdhury, A. \& A.K. Hazra (2008). Occurrence of the Earthworm Perionyx simlaensis (Michaelsen) from West Bengal. Journal of Threatened Taxa (in press).

Chowdhury, A., A.K. Hazra \& A.P. Nandi (2008). On taxonomy and ecology of earthworms (annelida: oligochaeta) from uncultivated and waste disposal sites of West Bengal with some notes on their microbial association. Records of the Zoological Survey of India (in press).

Gates, G.E. (1937). Indian earthworms. I. The genus Pheretima. Records of the Indian Museum 39: 175-212.

Gates, G.E. (1938a). Indian earthworms. III. The genus Eutyphoeus. Records of the Indian Museum 40: 39-119.

Gates, G.E. (1938b). Indian earthworms. IV. The genus Lampito Kinberg. V. Nellogaster gen. nov., with a note on Indian species of Woodwardiella. Records of the Indian Museum 40: 423-429.

Gates, G.E. (1951). On the earthworms of Saharanpur, Dehra Dun and some Himalayan Hillstations. Proceedings of the National Academy of Sciences of India 21: 16-22.

Gates, G.E. (1958). Contribution to a revision of the earthworm family Lumbricidae II. Indian species. Bulletin of the Museum of Comparative Zoology at Harvard College 91: 1-16.

Gates, G.E. (1972). Burmese earthworms. An introduction to the systematics and biology of megadrile oligochaetes with special reference to southeast Asia. Transactions of the American Philosophical Society 62(7): 1-326.

Halder, K.R. (1998). Annelida: Oligochaeta: Earthworms. In: State 

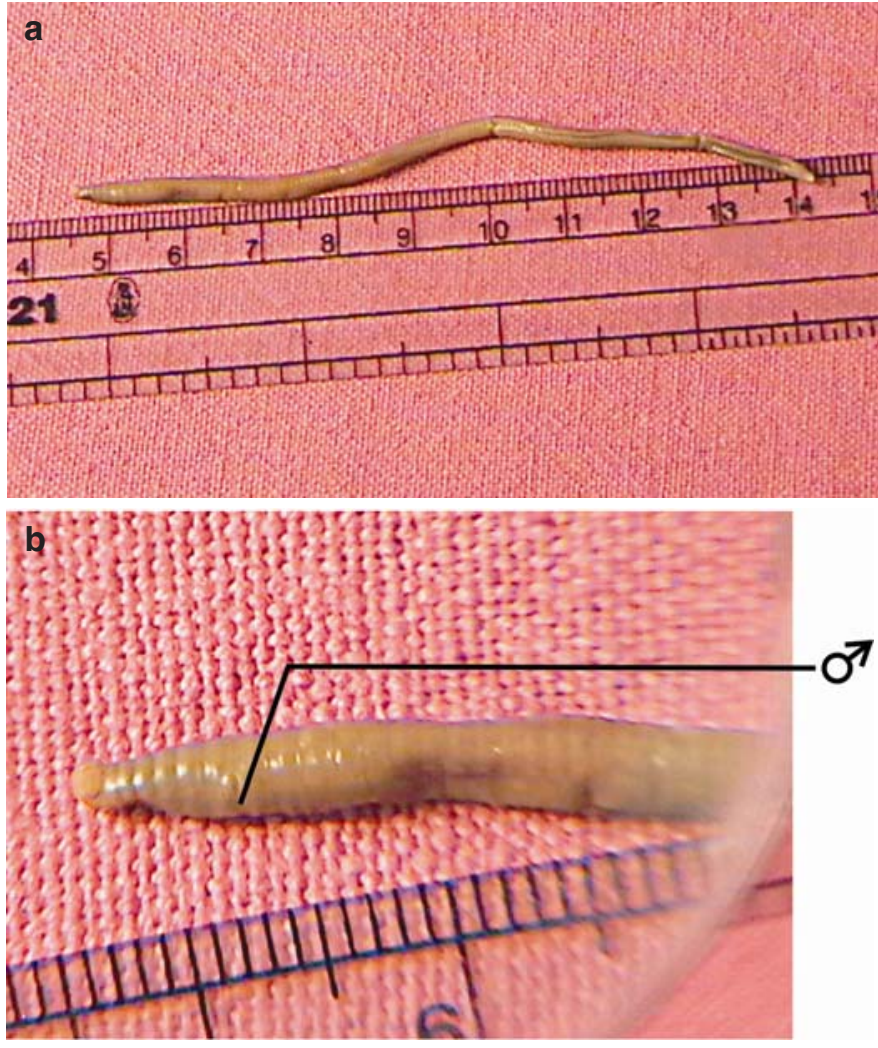

Image 1. Drawida papillifer papillifer Stephenson. a - Entire worm, ventro-lateral view; b - Anterior end showing male genital region.

Fauna Series 3 (Zoological Survey of India): Fauna of West Bengal 10: 17-93.

Halder, K.R. \& J.M. Julka (1967). On the occurrence of Pheretima peguana (Rosa) (Oligochaeta: Megascolicidae) from Kolkata. Current Science 36(17): 467.

Julka, J. M. (1975). Notes on the earthworms from Darjeeling district, with descriptions of two new species. Mitteilungen Aus Dem Zoologischen Museum in Berlin 51(1): 19-27.

Michaelsen, W. (1907). Neue Oligochaeten von Vorderindien, Ceylon, Birma und der Andaman Inseln. Jahrbuch der Hamburgischen Wissenschaftlichen Anstalten 24: 143-188.

Michaelsen, W. (1910). Die Oligochaeten fauna der Vorderindischceylonischen Region. Abhandlungen aus dem Gebiete der Naturwissenschaften, Hamburg 19 (5): 1-108.

Perrier, E. (1872). Récherches pour sevir á l' histoire des Lombriciens terrestres. Nouvelles archives du Museum d'Histoire Naturelle, Paris 8: 5-198.

Soota, T.D. \& K.R. Halder (1977). A new locality of Metaphire californica (Kinberg, 1867) (Oligochaeta: Megascolecidae) from

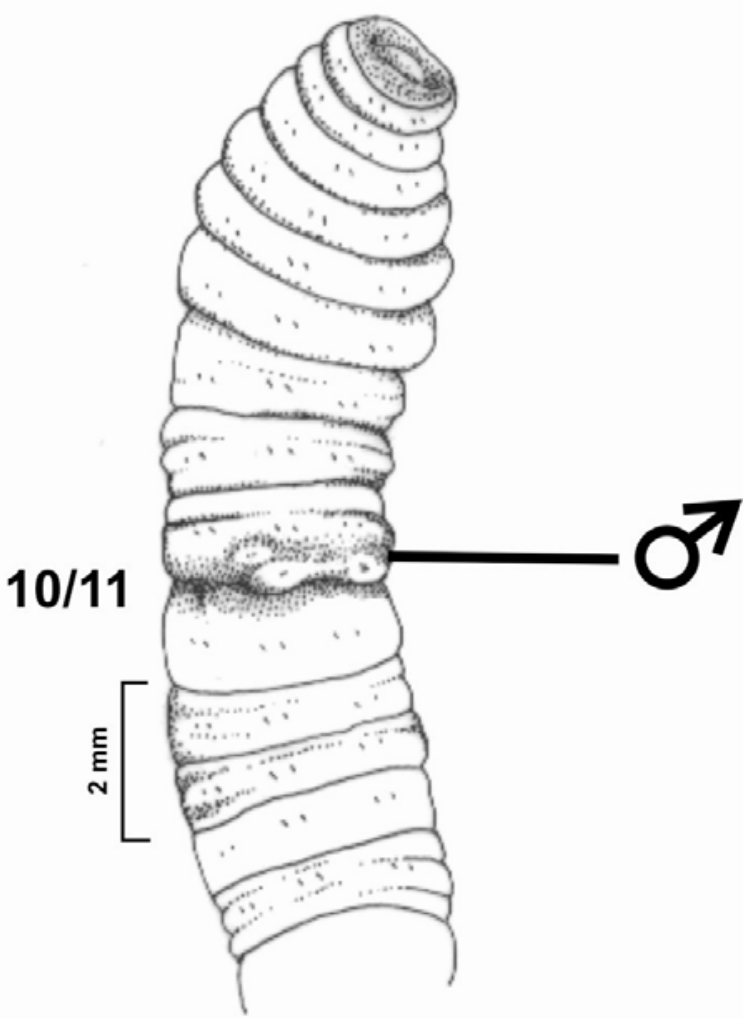

Figure 1. Anterior end of Drawida papillifer papillifer Stephenson, ventral view.

Kalimpong, Darjiling district, West Bengal. Newsletter of the Zoological Survey of India 3(3): 129.

Soota, T.D. \& K.R. Halder (1981). On some earthworms from eastern Himalayas. Records of the Zoological Survey of India 79: 231234.

Stephenson, J. (1916). On a collection of Oligochaeta belonging to the Indian Museum. Records of the Indian Museum 12: 299-354.

Stephenson, J. (1917). On a collection of Oligochaeta from various parts of India and further India. Records of the Indian Museum 13: 353-416.

Stephenson, J. (1920). On a collection of Oligochaeta from the lesser known parts of India and from eastern Persia. Memoirs of the Indian Museum 7: 191-261.

Stephenson, J. (1923). Oligochaeta: The Fauna of British India including Ceylon and Burma. Taylor and Francis Ltd., London, xxiv + 518pp. 